LANGUAGE BIRTH
MAC ADITIAWARMAN
Volume 1 Nomor 1
JILP
ISSN: 2581-0804
E-ISSN: 2581-1819

\title{
ABSTRACT
}

Language birth is a kind of event where a language appear and used by the community. Language birth through long process. Language birth can be formed by mixing of two or more languages. The formation of a new language is usually the result of a mixture of vocabulary. The mixing of the vocabulary will be mastered by one of the languages called the matrix language.
The matrix language has a strong position in the new language because the matrix language controls the development of the new language. Merging two or more languages takes considerable time until the language becomes a new permanent language like Tiong $\mathrm{Pa}$ language in Padang, West Sumatera, Indonesia.

Keywords: language birth, mixing, matrix, permanent

\section{KELAHIRAN BAHASA}

\begin{abstract}
ABSTRAK
Kelahiran bahasa adalah kemunculan masyarakat bahasa. Kelahiran sebuah bahasa melalui proses yang cukup panjang. Kelahiran bahasa dapat dibentuk oleh unsur gabungan dua bahasa atau lebih yang menghasilkan percampuran kosakata. Percampuran kosakata tersebut dikuasai oleh bahasa matriks. Bahasa

sebuah bahasa baru yang di ucapkan oleh suatu matriks tersebut memiliki kedudukan yang kuat karena menguasai bahasa baru itu. Penggabungan dua bahasa atau lebih membutuhkan waktu yang cukup panjang seperti bahasa Tiong Pa di Padang, Sumatera Barat, Indonesia.
\end{abstract}

\section{Kata kunci: kelahiran bahasa, percampuran, matriks, permanen}

\section{PENDAHULUAN}

Dalam kehidupan sehari-hari yang penuh dengan aktivitas, manusia sampai-sampai tidak sempat berpikir tentang alam sekitarnya. Kepadatan aktivitas ini kadang-kadang membuat manusia seakan-akan tak peduli dengan sesama manusia, bahkan terhadap dirinya pun tidak peduli. Dari sekian banyak hal yang terabaikan, ada sebuah pertanyaan yang tidak pernah terjawab oleh para ahli bahasa, yaitu tentang Kapan bahasa pertama kali lahir dan bahasa 
apakah itu? Ataukah Bahasa pertama yang lahir ke dunia ini lebih dari satu? Perdebatan dan silang pendapat di tengah-tengah para ahli bahasa telah terjadi, masing-masing saling mengeluarkan pandangan dan argumennya. Namun, tidak satu pun yang merasa puas begitu saja dan setuju dengan pendapat para ahli bahasa. Selanjutnya, Apakah bahasa lahir berpasangpasangan juga seperti makhkluk hidup ciptaan Tuhan? Yang jelas, sampai sekarang belum ada ahli bahasa yang memberikan argumen memadai yang dapat meyakinkan manusia tentang bahasa yang pertama kali ada di dunia ini.

Kelahiran bahasa yang pertama di dunia dapat dilacak dari kitab-kitab keagamaan yang turun dari Tuhan, seperti Taurat, Zabur, Injil, dan Al Qur'an. Pada keempat kitab suci itu disebutkan bahwa Tuhan menciptakan manusia. Sebelum Tuhan menciptakan sesuatu apapun, Dia menciptakan Nur Muhammad. Pada saat penciptaan Nur Muhammad itulah terjadi dialog antara Tuhan dengan Nur Muhammad. Dengan demikian, dapat dikatakan bahwa bahasa untuk pertama kalinya dipakai oleh Tuhan dengan ciptaan-Nya. Kalau demikian adanya, manusia tidak dapat menentukan kapan bahasa yang pertama lahir, tetapi yang jelas bahasa itu ada pada sang Pencipta.

Teka-teki tentang bahasa selanjutnya adalah Bahasa apa yang dipergunakan pertama kalinya? Berdasarkan uraian di atas, bahwa yang menggunakan (penutur) bahasa pertama adalah Tuhan dan lawan bicara (petutur) adalah Nur Muhammad. Dengan mengambil patokan dari dasar-dasar informasi itu, maka dapat diperkirakan bahawa bahasa yang digunakan oleh Tuhan dan Nur Muhammad saat berdialog adalah bahasa Hebrew atau bahasa Ibrani (Ibrn) sama dengan bahasa yang ada dalam bahasabahasa kitab suci yang diturunkan Allah kepada Nabi-nabi-Nya.

Setelah penciptaan manusia pertama, Adam dan disusul oleh Hawa, bahasa itu tetap dipergunakan sebagai alat untuk berkomunikasi. Karena adanya suatu tragedi, maka Adam dan Hawa dilemparkan ke dunia dan di sinilah mereka berkembang. Perkembangan umat manusia sudah pasti akan mempengaruhi perkembangan bahasa pula. Manusia berkembang, lalu mereka berpencar mencari tempat-tempat baru untuk mencari nafkah demi kelangsungan hidup mereka. Semakin hari, kebutuhan manusia semakin meningkat, begitu pula kebutuhan terhadap kebendaan. Bendabenda yang tadinya belum memiliki nama terpaksa harus dicarikan namanya, sehingga hal ini menimbulkan dampak kepada pertumbuhan dan perkembangan terhadap kosakata mereka. Berbeda tempat yang ditempati oleh manusia, berbeda pula benda-benda yang dibutuhkan manusia. Kelompok-kelompok manusia yang berpencar itu sudah memiliki jumlah kosakata berbeda sesuai dengan tempat dan kebutuhan mereka masing-masing. Bila pada suatu waktu tertentu kelompok yang berpisah itu bertemu, maka bahasa yang mereka miliki awalnya sama, sekarang sudah banyak terdapat perbedaan, maka keduanya akan berinteraksi antara yang satu dengan yang lain dan akan saling memperkaya. Bila penggabungan dua bahasa terjadi akibat sebuah peperangan, maka biasanya bahasa kaum yang kalah memungut bahasa kaum yang menang karena secara psikologis kedudukan sosial pihak yang menang pasti lebih tinggi, sehingga hal ini juga mempengaruhi wilayah kebahasaan mereka yang kalah. Bahasa penakluk 
dianggap atau dirasakan memiliki status atu gengsi sosial bahasa tersendiri. Oleh sebab itu, kaum yang dikalahkan memperlihatkan kecenderungan mempelajari bahasa yang kaum yang menang karena dianggap lebih bergengsi. Kemungkinan lain pembelajaran terhadap bahasa kaum yang menang adalah karena adanya pemaksaan terhadap kaum yang kalah harus mempelajari bahasa mereka dan melarang penggunaan bahasa kaum yang kalah.

Jika manusia ingin merenungkan lebih merinci lagi tentang penciptaan manusia dan bahasa, maka sebagai bahan pertimbangan dapat dilihat dari penciptaan manusia itu sendiri oleh sang pencipta (khalik). Tuhan menciptakan manusia lengkap dengan segala peralatan yang diperlukan oleh manusia untuk menjalankan hidupnya. Sebagai contoh, untuk menempuh kehidupan, Tuhan memberikan otak kepada manusia untuk berpikir. Bila otak itu diteliti lebih saksama, maka terlihat bahwa otak itu terbagi atas dua bahagian, yaitu otak kiri (yang dalam linguistik disebut sebagai left hemisphere) dan otak kanan (right hemisphere). Kedua belah otak yang dianugerahkan oleh Tuhan kepada manusia, masing-masingnya sudah memiliki tugas sendirisendiri pula. Otak manusia yang terletak di sebelah kanan (right hemisphere) diberikan tugas dan berfungsi untuk mempelajari bahasa, sedangkan otak manusia sebelah kiri (left hemisphere) untuk melakukan aktivitas bagi manusia. Manusia sudah dipersiapkan oleh Tuhan untuk menampung kemampuan bahasanya sendiri-sendiri.

Bahasa diperoleh oleh manusia melalui sebuah proses pembelajaran dan proses itu harus dibimbing oleh manusia sebelumnya. Bahasa tidak dapat datang dengan sendirinya, harus dipelajari. Hal ini dapat diperkuat dengan sebuah eksperimen, yaitu dengan cara mengisolasi seorang bayi yang baru lahir lansung diisolasi tanpa berhubungan dengan manusia lain, maka dapat dipastikan bayi itu kelak kalau sudah tumbuh dan besar tidak bisa menggunakan bahasa sama-sekali karena tidak melewati proses pembelajaran bahasa. Pemerolehan bahasa (language acquisition) pertama oleh bayi adalah dengan jalan meniru dari orang tuanya, dan orang tuanya itu bertindak sebagai guru bahasa pertama bagi anaknya. Di samping pengajaran bahasa yang diperoleh dari orang tua seorang bayi, lingkungan juga ikut mempercepat dan memperkaya bahasa bayi tersebut. Bahasa yang diperoleh dan dikuasai oleh bayi itu disebut sebagai bahasa ibunya (mother language) dan sekaligus sebagai penutur asli (native speaker). Menyangkut istilah mother language (bahasa ibu) dan native speaker (penutur asli) dapat dijelaskan sebagai berikut:

1. Mother language (bahasa ibu) adalah bahasa bahasa yang dipelajari pertama dari kecil dan menjadi bahasa pengantar seharihari. Seseorang yang memiliki mother language (bahasa ibu) A, sudah otomatis menjadi native speaker (penutur asli) bahasa A tersebut.

2. Native speaker (penutur asli) adalah orang yang dapat berkonmunikasi dengan menggunakan bahasa $\mathrm{X}$ dalam jangka waktu yang cukup lama dan dengan menggunakan kalimat-kalimat komplek dalam bahasa $\mathrm{X}$ tersebut. Bagi seseorang yang native speaker (penutur asli) dari bahasa $\mathrm{X}$, bahasa $\mathrm{X}$ tidak berstatus sebagai mother language (bahasa ibu). Dengan kata lain, seseorang yang memiliki native 
language (bahasa ibu) X sudah pasti seorang penutur asli, sedangkan seseorang yang native speaker (penutur asli) belum tentu berasal dari kelompok yang mother language.

Tuhan memang telah menciptakan manusia selalu dilengkapi dengan bahasa. Tuhan tidak membedakan status sosial, tingkat pendidikan, jenis kelamin, dan bahkan tidak membedakan antara manusia yang normal dan yang tidak normal. Kalau kita melirik ke sekeliling kita, rasanya tidak ada satu pun manusia yang tidak pandai berbahasa. Bahkan, seorang yang idiot dan bisu juga dapat berbahasa. Pada orang yang bisu, mereka mengunakan bahasa isyarat (gesture). Tuhan menciptakan dua jenis bahasa, yaitu bahasa verbal (bahasa yang menggunakan alat ucap dan menghasilkan bunyi-bunyi bahasa) dan bahasa nonverbal (termasuk bahasa isyarat). Dengan demikian, dapat dikatakan bahwa semua makhkluk ciptaan Tuhan selalu dibekali dengan bahasa. Hanya saja, manusia tidak dapat mengerti bahasa hewan, atau sebaliknya. Tetapi, untuk kasus-kasus tertentu, hewan dapat mengerti perintah-perintah manusia kepada mereka, seperti hewan yang digunakan dalam sirkus atau beberapa jenis binatang peliharaan manusia.Pendapat yang penulis kemukakan di atas ada yang berbeda dengan pendapat para ahli bahasa tentang kelahiran bahasa pertama (bahasa asli). Para ahli berpikir bahwa manusia memperoleh bahasa setelah mereka dihadirkan Tuhan ke dunia. Padahal, Tuhan sudah membekalinya dengan bahasa sejak mereka belum dihadirkan ke dunia ini. Pandangan para ahli yang mengemukakan bahwa bahasa itu diperoleh di dunia ini dapat dilihat pada teori- teori sebagai berikut.

Menurut Aitchison (1985), tentang kelahiran bahasa (language Birth) merupakan masalah yang tak terpecahkan oleh pakar bahasa. Banyak orang bertanya-tanya tentang begaimana bahasa muncul pertama kalinya, yaitu asal bahasa yang asli. Ada beberapa teori yang dikemukan para ahli bahasa tentang bahasa yang pertama kali ada, antara lain:

1. Teori Din-dong, yaitu teori yang menyatakan bahwa kata-kata pada awalnya merupakan peniruan bunyi alam, seperti bang!, Cuckoo, Splash!, Moo!.

2. Teori Pooh-pooh, yaitu teori yang menyatakan bahwa bahasa timbul karena jeritan dan hembusan nafas emosi.

3. Teori Yo-He-Ho, yaitu teori yang menyatakan bahwa bahasa muncul berdasarkan atas usaha komunal, dengan instruksi-instruksi seperti Heave! Haul!

Teori-teori yang telah dikemukakan di atas tidak dapat memberikan penjelasan tentang bagaimana proses bahasa terbentuk untuk pertama kalinya. Buku ini tidak membahas bagaimana bahasa terbentuk pertama kalinya, atau terbentuk bahasa asli yang pertama di dunia ini. Buku ini akan menjelaskan bagaimana sebuah bahasa baru muncul yang diakibatkan oleh pertemuan antara kelompok-kelompok sosial bahasa berbeda yang didesak oleh kebutuhan hidup untuk saling berinteraksi dengan jalan melakukan komunikasi. Manusia mana pun tidak kuasa menghindarkan diri dari kebutuhan hidup berupa kegiatan berinteraksi dengan manusia lain, bahkan dengan manusia yang berasal dari kelompok sosial bahasa berbeda sekali pun. 


\section{BAGAIMANA PIDGIN MUNCUL?}

Pidgin (pijin) sering disebut sebagai sebuah bahasa marginal, digunakan orang untuk berkomunikasi dengan tujuan tertentu. Pidgin memperlihatkan kecenderungannya muncul pada jalur perdagangan, sebagai contoh, sepanjang pantai Afrika Barat, di Carabean, dan pulaupulau Pasifik. Teori yang sangat terkenal adalah berasal dari China English Pidgin di mana kata pidgin berarti business, seperti dalam gospin man (artinya good-business-man). Teori lain mengatakan bahwa kata pidgin berasal dari bahasa Hebrew pijom 'barter'. Barangkali ungkapan yang sama muncul secara bebas pada tempat-tempat berbeda, dan kemudian saling memperkuat antara yang satu dengan yang lainnya, bergabung dalam sebuah ungkapan pidgin.

Umumnya, sebuah pidgin mengambil satu bahasa atau lebih dari bahasa yang sudah ada sebagai bahasa aslinya atau bahasa dasarnya (lebih dikenal dengan istilah matrix language dalam code mixing dan code switching). Sebagai contohnya, kita ambil saja Tok Pisin, pidgin yang berdasarkan bahasa Inggris yang ditemukan di New Guinea, pidgin Melanesia, atau NeoMelanesia yang sudah berumur kurang lebih seabad. Di sini ditemukan gejala-gejala seperti kata $m i$ untuk $I$ dan $m e$ dan kata $Y u$ untuk $Y o u$. Amatilah contoh berikut:

1. mi go 'I go', $y u$ go 'You go'

2. mi lukim $y u$ 'I see you', $y u$ lukim mi 'you see me'

Posesif bahasa Inggris 'my, your, our, dan seterusnya diunggkapkan dengan penggunaan kata bilong (berasal dari bahasa Inggris belong). Selanjutnya dapat pula ditemukan frasa-frasa seperti berikut.
3. papa bilong $m i$ 'my father'

4. haus bilong mipela 'our house'

5. gras bilong het 'hair' (berasal dari 'grass of head')

6. gras bilong fes 'beard' (berasal dari 'grass of face')

7. gras bilong pisin 'bird feather' (berasal dari 'grass of pigeon')

8. gras bilong solwara 'seaweed' (berasal dari 'grass of saltwater')

9. gras bilong paia 'ash' (berasal dari 'excrement of fire')

10. sit bilong lam 'soot' (berasal dari 'excremment of lamp')

11. papa bilong $y u$ 'your father'

12. haus bilong yupela 'your (plural) house'

Pada awal kemunculannya, pidgin dianggap oleh banyak orang sebagai sebuah bahasa rendahan, karena bahasa tersebut dipandang sebagai bahasa rusak yang tidak layak untuk dipelajari. Namun, Hugo Schuchardt, seorang sarjana abad kesembilan belas berpendapat lain. Ia berpandangan bahwa pidgin adalah sebuah bahasa yang layak dipelajari seperti bahasa-bahasa lain yang ada di dunia ini. Sejak Hugo mengeluarkan pendapatnya bahwa pidgin adalah sebuah bahasa yang layak dipelajari, artinya pidgin memiliki hak dan status yang sama dengan bahasa mana pun, barulah dua puluh tahun terakhir ini pidgin mendapat perhatian kalangan ahli bahasa. Perjalanan panjang yang memakan waktu cukup lama, akhirnya membuahkan hasil juga. Meskipun pengakuan yang dinantikan itu akhirnya tiba juga, tetapi pengakuan itu sudah mengalami keterlambatan, karena saat pengakuan itu muncul sudah banyak pidgin yang hilang dan tidak sempat dicatat. Dengan kata lain, dunia bahasa 
sudah kehilangan sesuatu yang amat berharga yang diakibatkan oleh ketidaksepakatan para pakar bahasa terhadap pidgin dimasukkan ke dalam sebuah bahasa. Perdebatan para ahli bahasa itu memakan waktu yang panjang, sehingga sebelum kata sepakat dapat dicapai, pidgin-pidgin tersebut sudah duluan menghilang dari muka bumi ini sebelum para ahli bahasa sempat mendokumentasikannya. Akibat terlambatnya inisiatif yang diambil oleh para ahli bahasa, maka satu per satu aset dunia kebahasaan menghilang karena mereka bersikukuh mempertahankan ego masing-masing. Sejak munculnya kesadaran akan kehilangan aset dunia kebahasaan itu, maka para pakar bahasa berusaha mengumpulkan informasi-informasi tentang bahasa pidgin yang masih tersisa. Dewasa ini telah muncul beberapa teori tentang pidgin asli, yaitu:

1. Teori pertama, mengatakan bahwa pidgin muncul akibat pembelajaran bahasa yang tidak sempurna. Menurut sudut pandang teori ini, sekelompok orang yang sudah dewasa mempelajari bahasa yang baru, hasilnya pasti akan berbeda dengan anakanak yang mempelajari bahasa tersebut dari awal. Bentuk-bentuk tuturan yang dihasilkan orang dewasa lebih sederhana jika dibandingkan dengan bentuk-bentuk tuturan yang dihasilkan oleh anak-anak.

2. Teori Kedua, menyatakan bahwa pidgin terbentuk akibat penutur asli menggunakan suatu cara dalam rangka membantu nonpenutur asli agar dapat dengan mudah mempelajari bahasa asli tersebut. Cara yang digunakan oleh penutur asli tersebut sesungguhnya tidak merek sadari sama sekali, terjadi secara natural saja.

Dalam hal ini, penutur asli memainkan peranan yang penting dalam perubahan suatu bahasa. Artinya, perubahan yang terjadi pada bahasa asli tersebut bukan dilakukan oleh non-penutur asli, melainkan oleh penutur asli.

3. Teori monogenetik (kelahiran tunggal) mengatakan bahwa pidgin berasal dari bahasa Portugis karena sejumlah besar kosakata bahasa Portugis ditemukan dalam pidgin. Teori ini tidak dapat diterima karena:

(a) tidak dapat dibuktikan, dan

(b) bahasa-bahasa pidgin juga ditemukan dengan ciri bahasabahasa non-Eropa. Kenayataan ini dapat dilihat pada perjalanan dari pidgin ke kreol bahasa Tiong $\mathrm{Pa}$ di Padang. Bahasa Tiong Pa kreol bahasa Minangkabau ini awalnya tidak dipengaruhi unsur bahasabahasa Eropa.

\section{PERUBAHAN BAHASA}

Setiap bahasa dapat saja mengalami perubahan tanpa ada yang dapat menduga dan mentedeksinya. Para ahli bahasa hanya dapat memberikan penjelasan tentang gejala perubahan

bahasa tersebut. Salah satu penjelasan yang dianggap sebagai suatu dasar pandangan perubahan adalah penjelasan model oleh Thomson dan Kaufman (1988). Kedua ahli bahasa ini menjelaskan bahwa pada peristiwa 
peminjaman bahasa, bahasa pertama (B1) dipelihara, tetapi mereka membuka diri dalam menerima bentuk bahasa baru dari bahasa kedua, yaitu B2. Dalam alih kode, B1 berkedudukan sebagai bahasa matrik (matrix language/ML), sedangkan B2 sebagai embedded language (EL). Dalam perubahan bahasa, dapat ditemukan juga kenyataan bahwa ML dilepaskan secara perlahan-lahan kemudian beralih kepada EL sebagai ML yang baru. Gejala awal dimulai dari pinzaman leksikal, setelah itu perubahan pun terjadi, yaitu dari language pertama (L1) kepada language kedua (L2) sebagai ML.

Myers (1997) menjelaskan bahwa yang menjadi kunci dalam suatu perubahan bahasa (dalam hal ini morfosintaksisnya) adalah tergantung kepada bahasa yang mana yang menjadi ML selama alih kode berlangsung. ML dapat dijadikan landasan bahasa yang mendominasi gejala perubahan bahasa itu karena ML memiliki kecenderungan memberikan identitas bahasa-bahasa campuran yang baru terbentuk. Dalam sebuah kreol, dapat dikatakan bahwa bahasa yang memiliki unsur terbanyaklah yang dipastikan sebagai ML. Dengan demikian, identitas bahasa terbesar yang dikandung oleh kreol itu adalah berasal dari ML-nya.

Perubahan sebuah bahasa, pada awalnya dimulai dari peristiwa kontak bahasa, meningkat ke arah situasi saling mempengaruhi, kemudian barulah terjadi perubahan bahasa tersebut. Perubahan bahasa yang bermula dari kontak bahasa tidak dapat dipisahkan dari gejala code mixing (campur kode) dan code switching (alih kode).

\section{A Skenario Alih Kode Menurut Aitchison Menurut Aitchison (1985), ada tujuh}

skenario yang dapat dijadikan landasan dalam mengamati sebuah peristiwa alih kode. Pada bahasa yang beralih kode, yang perlu menjadi patokan adalah ML dan EL. Dalam sebuah alih kode, unsur-unsur bahasa yang terlihat adalah berasal dari ML dan EL yang berupa morfosintaksisnya. Ketujuh skenario ancangan Aitchison (1985) dapat dilihat pada uraian berikut.

\section{$1 \quad$ Skenario I}

Morfem-morfem inti yang dipinjam dari L1 dipelihara sebagai bahasa utama masyarakat. Selama alih kode sedang berlangsung pada sebuah bahasa, tidak mudah bagi morfosintaksis EL mempengaruhi ML, begitu juga morfemmorfem inti EL untuk memasuki ML.

\section{Skenario II}

ML dapat menerima gabungan morfemmorfem inti EL sebagai langkah lanjutan dalam peristiwa alih kode.

\section{Skenario III}

Dalam alih kode, bahasa donor bisanya dianggap lebih memiliki wibawa secara sosiopolitik dan sosioekonomi jika dibandingkan dengan bahasa penerimanya.

\section{Skenario IV}

Dalam perjalanan alih kode tertentu, sebuah bahasa awalnya berkedudukan sebagai ML, tetapi setelah menjalani proses waktu yang cukup panjang, bisa saja pertukaran tataran terjadi. Bahasa yang sebelumnya bekedudukan sebagai ML dapat berubah menjadi EL setelah melewati rentang waktu tertentu.

\section{Skenario V}

Dengan adanya pengaruh morfosintaksis ML yang baru,biasanya penutur secara otomatis mengubah pengucapan mereka 


\footnotetext{
dari bahasa utama ke bahasa kedua ketika peristiwa alih kode sedang berlangsung, sehingga muncullah ML baru yang berasal dari hasil perjalanan alih kode.

\section{Skenario VI}

Pada saat alih kode berlangsung, ML yang pertama perlahan-lahan tidak lagi digunakan oleh penuturnya. Akibat penutur meniggalkan ML pertama dan beralih kepada ML yang baru, maka ML yang pertama tadi secara berangsur-angsur ditinggalakan dan menjadi bahasa sekarat (dalam linguistik lebih dikenal dengan istilah dying language). Akhirnya, unsur bahasa yang masih tetap tersisa hanya dapat dilihat dalam bentuk ungkapanungkapan salam (formulaic).
}

\section{Skenario VII}

Alih kode merupakan suatu alat dalam pembentukan Pidgin dan Kreol. Alih kode terjadi karena ada peristiwa interaksi social masyarakat bahasa satu dengan yang lainnya.

\section{B Skenario Perubahan Bahasa Menurut Appel dan Pieter}

Di samping skenario yang telah dikemukakan oleh Aitchison (1988), pada tahun yang sama, Appel dan Pieter (1988) juga mengemukakan skenario tentang perubahan bahasa. Berbeda dari skenario Aitchison, skenario yang dikemukakan Appel dan Pieter terdiri atas lima poin. Konsep lima skenario yang dikemukakan oleh Appel dan Pieter didasarkan atas konsep:
1) melalui penyatuan,
2) melalui pengaruh kultur dan pinzaman leksikal,
3) melalui pembelajaran/pemerolehan bahasa,
4) melalui releksifikasi, dan
5) melalui pembelajaran.

Kelima konsep skenario tersebut di atas dapat dilihat pada penjelasan berikut ini.

\section{Skenario 1}

Penyatuan perlahan-lahan dua bahasa atau lebih dapatdiakibatkan karena lama hidup berdampingan. Penyatuan bahasa ini terjadi karena masyarakat penutur bahasa hidup dalam situasi yang sama, dalam daerah yang sama, dalam waktu yang lama, dan orang yang sama pula, sehingga bahasa mereka cenderung menyatu. Penyatuan ini sangat jelas terlihat pada tingkat fonetik. Waktu, tempat, situasi, dan penutur yang sama dapat mengakibatkan sistem-sistem bunyi bahasa tumbuh menjadi sama pula.

\section{Skenario 2}

Skenario yang sangat penting adalah pengaruh budaya yang tercermin melalui pinzaman leksikal. Pinzaman leksikal ini terwujud dalam bentuk pinzaman katakata.

\section{Skenario 3}

Releksifikasi adalah penggantian kosakata dari suatu bahasa dengan kosakata bahasa lain secara besar-besaran, sedangkan gramatika aslinya masih tetap dipelihara. Kadang-kadang gramatika bahasa asli juga dapat berubah.

\section{Skenario 4}

Bahasa anak (daughter language) dapat menyimpang dari bahasa ibu (mother 
language). Hal tersebut dapat terjadi bila suatu bahasa dibawa oleh penuturnya ke daerah lain, selanjutnya penutur bahasa lain tersebut mengambilnya sebagai bahasa kedua. Pengambilan bahasa yang baru datang itu sebagai bahasa kedua dapat dikarenakan adanya anggapan bahwa bahasa kedua itu memiliki wibawa kebudayaannya dan wibawa politik lebih tinggi daripada bahasa pertama. Kemungkinan besar bahasa asli secara perlahan-lahan dipengaruhi oleh bahasa baru tersebut.

\section{Skenario 5}

Pola-pola bahasa yang dianggap berwibawa oleh penutur suatu bahasa sering ditiru oleh penutur bahasa lain. Sebagai indikasi penentu bahwa bahasa dianggap sebagai sebuah bahasa berwibawa dapat diukur dari sosioekonomi dan sosiopolitik oleh penutur dari bahasa lain.

\section{Alih Kode dan Campur Kode}

Alih kode (code switching) dan campur kode (code mixing) memainkan peranan penting dalam perubahan bahasa. Kedua gejala ini tidak dapat dihindari oleh bahasa yang dinamis. Peristiwa ini tidak dapat dihindari karena para penutur bahasa tersebut dituntut oleh kodrat mereka sebagai manusia yang memiliki sifat universal, yaitu memiliki kemampuan untuk berintegrasi dan bersosialisasi dengan para penutur dari bahasa berbeda. Oleh karena itu, sangat kecil kemungkinan bagi sebuah bahasa untuk bersifat statis, meskipun masyarakatnya terisolasi dari masyarakat bahasa lain. Masyarakat bahasa yang terisolasi dari masyarakat bahasa lain tidak dapat bertahan selamanya, karena mereka dituntut oleh kebutuhan hidupnya. Ferdinan de Saussure, pendiri strukturalisme mengemukakan bahwa bahasa adalah suatu system out tout se tien (saling ketergantungan). Pandangan ini menganggap bahasa-bahasa adalah alat yang sangat komplek yang berhubungan dengan dunia dan komunikasi, dan alat ini dengan mudah beradabtasi dengan kebutuhan komunikasi dan kebutuhan akan rujukan yang baru.

\section{Alih Kode}

Alih kode adalah peristiwa peralihan dari satu kode ke kode yang lain. Apabila seorang penutur bahasa (kode) X, kemudian secara spontan beralih ke bahasa (kode) Y, maka peristiwa kebahasaan demikian disebut sebagai alih kode. Peristiwa alih kode ini biasa terjadi pada masyarakat bahasa yang dwibahasawan atau multibahasawan. Alih kode merupakan salah satu aspek ketergantungan bahasa (language dependency) dalam masyarakat multilingual.

Dari segi sifatnya, alih kode dapat dibagi atas: (1) alih kode yang bersifat intern, yaitu alih kode yang terjadi antarbahasa-bahasa daerah dalam lingkunagn satu bahasa nasional, atau antarragam dan gaya dalam satu dialek, (2) alih kode yang bersifat ekstern, yaitu alih kode yang terjadi antar bahasa asli dengan bahasa asing. Dalam suatu tuturan mungkin saja terjadi alih kode besifat intern dan ekstern secara bersamaan.

Alih kode intern seperti yang telah dijelaskan di atas merupakan salah satu gejala dalam perubahan suatu bahasa. Perubahan bahasa demikian dapat terjadi antara bahasa daerah dan bahasa nasional. Berikut ini dapat 
dilihat contoh alih kode intern antara bahasa Indonesia dan bahasa Minangkabau.

13. Bapak : Dony, kamu belajar yang benar dong. Ko indak, baraja sambia bamain juo. Anak : Dony kan sudah belajar Pak. Banyak bana aturan dek Apak mah.

Contoh di atas mencerminkan alih kode antara bahasa nasional dan bahasa daerah (bahasa Minangkabau). Kalimat Ko indak, baraja sambia bamain juo 'ini tidak, belajar sambil bermain' dan Banyak bana aturan dek Apak mah ' banyak sekali aturan dari Bapak' adalah kalimat yang berasal dari bahasa Minangkabau. Pada contoh tersebut telah terjadi alih kode intern yang diakibatkan oleh adanya gejala pergeseran bahasa pada masyarakat Minangkabau. Pada umumnya, di dalam rumah tangga masyarakat Minangkabau sudah menggunakan bahasa Indonesia sebagai bahasa pengantar di tengah-tengah anggota keluarga. Meskipun demikian, para orang tua masih terpengaruh oleh bahasa Minangkabau karena mereka dibesarkan dalam lingkungan keluarga yang menggunakan bahasa Minangkabau, sehingga sukar bagi para orang tua tersebut untuk menghilangkan bahasa Minangkabau sebagai bahasa ibu mereka.

Khusus untuk jenis alih kode ekstern, sangat jarang ditemukan pada masyarakat Minangkabau. Penggunaan alih kode biasanya ditemukan pada masyarakat yang pernah mencicipi pendidikan di sekolah Belanda pada zaman penjajahan. Penggunaan alih kode jenis ekstern sudah merupakan sesuatu kebanggaan bagi mereka, karena mereka merasa bahwa mereka termasuk ke dalam kelompok status sosial tinggi jika dibandingkan dengan masyarakat yang tidak pernah mencicipi pendidikan Belanda tersebut. Kelompok ini banyak ditemukan di pulau Jawa, seperti kaum Menak di tanah Priyangan atau kaum Priyai.

\section{Campur Kode}

Campur kode terjadi pada masyarakat bahasa yang dwibahasawan atau multibahasawan. Campur kode terjadi akibat desakan kebutuhan hidup bagi masyarakat penutur bahasa tersebut. Kebutuhan hidup itu tidak terlepas dari desakan kodrat manusia sebagai masyarakat sosial. Dalam masyarakat sosial sangat dibutuhkan interaksi sosial yang berpengaruh langsung terhadap bahasa mereka. Bahasa merupakan satu-satunya alat untuk berinteraksi dalam masyarakat.

Dalam kelompok sosial masyarakat yang multilingual (masyarakat multibahasawan) hampir tidak mungkin bagi seorang penutur menggunakan satu bahasa secara mutlak tanpa adanya pengaruh dari bahasa lain atau pengaruh unsur bahasa lain di dalam bahasa yang dituturkannya. Gejala seperti itu bukanlah suatu hal yang buruk, tetapi sebaliknya, bahasa akan dapat berkembang apabila bahasa tersebut melakukan kontak bahasa dengan bahasa lain. Bahasa yang tertutup terhadap bahasa lain cenderung statis, bahkan lebih parah lagi, bahasa tersebut bergerak ke arah dying language (bahasa sekarat).

Suwito (1983) membagi campur kode ini ke dalam dua jenis, yaitu: (1) yang bersumber dari bahasa asli dengan segala variasi-variasinya disebut sebagai campur kode ke dalam (inner code mixing), dan (2) campur kode yang unsurnya bersumber dari bahasa asing disebut 
sebagai campur kode ke luar (outer code mixing).

Dalam bahasa Tiong Pa banyak ditemukan campur kode antara unsur-unsur bahasa Indoensia, Miangkabau, bahkan masih ditemukan pula unsur-unsur bahasa Cina sebagai bahasa ibu yang digunakan oleh nenek moyang mereka yang datang dari dataran Tiongkok dulunya. Unsur-unsur bahasa Cina ini hanya tersisa dalam kelompok kata-kata budaya saja. Bahasa Cina yang dimiliki oleh etnis Tionghoa Padang hanya berstatus sebagai dying language (bahasa sekarat) karena bahasa tersebut tidak berkembang sama sekali, bahkan semakin menghilang dari lidah mereka. Berikut ini dapat dilihat bahasa Kreol Tiong Pa yang terbentuk akibat adanya peristiwa campur kode.

14. Lily (BTP) : Ing, baa kok suntuk se bantuk lu?

kamatian laki se

Bantuk orang

gua. Kalo lu ada nampak dek masalah

ceritakan se ka gua.

BMk : Ing, baa kok suntuak se bantuak kau? Bantuak urang kamatian laki se nampak dek den. Kalau kau ado masalah caritoan se ka den.

BI : Ing, mengapa kok suntuk saja wajah kamu?

Seperti orang kematian

kelihatannya oleh saya. suami saja Kalau kamu ada masalah ceritakan saja kepada saya.

Kata Ing pada kalimat Ing, baa kok suntuk se bantuk lu? Bantuk orang kamatian laki se nampak dek gua. Kalo lu ada masalah ceritakan se ka gua di atas merupakan singkatan dari nama penutur, yaitu Ang Siu Ing. Salah satu unsur bahasa Cina yang masih hidup di tengah-tengah mansyarakat etnis Ting Hoa Padang adalah nama orang, di samping nama makanan dan kata-kata yang termasuk kata-kata budaya. Kata baa, suntuk, kok, se, dan bantuk merupakan unsurunsur bahasa yang berasal dari bahasa Minangkabau, bahasa Indonesia, dan unsur bahasa Cina. Kata-kata baa, se, dan bantuk berasal dari bahasa Minangkabau. Kata baa berarti 'bagaimana/mengapa' dan kata se berarti 'saja'. Sedangkan kata bantuk 'bentuk' berasal dari kata bahasa Minangkabau yang diadopsi oleh etnis Tionghoa Padang dan telah mengalami perubahan. Kata bantuk berasal dari kata bantuak dalam bahasa Mianangkabau, tetapi karena akibat perubahan, maka telah terjadi pelesapan terhadap vowel/vokal /a/ yang terletak antara konsonan / $\mathrm{k} /$ dan / $/$ / dan berposisi sebagai silabe kedua dalam kata tersebut. Perubahan-perubahan sejenis sangat banyak ditemukan pada kosakata bahasa Minangkabau yang dituturkan oleh etnis Tionghoa di kota Padang.

Perubahan-perubahan yang dialami oleh kosakata yang diadopsi oleh bahasa lain merupakan hal yang biasa terjadi. Perubahan yang terjadi lebih diakibatkan oleh adanya perngaruh masyarakat penutur bahasa yang mengadopsinya. Gejala yang demikian merupakan suatu gejala yang alami (natural) dalam perjalanan sebuah bahasa dan sekaligus menunjukkan bahasa tersebut termasuk salah satu bahasa yang dinamis. Kedinamisan sebuah bahasa bukan terletak pada bahasa itu, malainkan pada masyarakat bahasanya. Bahasa yang memiliki kontak bahasa dengan bahasa lain akan memiliki kecenderungan mengadopsi unsurunsur bahasa yang berhubungan dengan bahasa 
tersebut.

Sesuai dengan perkembangan bahasa dewasa ini, bahasa Tiong Pa juga mengadopsi unsur-unsur bahasa asing sebagai usaha memperkaya bahasa Tiong $\mathrm{Pa}$ Kreol bahasa Minangkabau. Unsur-unsur bahasa asing yang diserap itu bukan saja berupa unsur asli (unsur yang belum mengalami penyesuyuaian dengan bahasa Indonesia) tetapi juga mengadopsi unsurunsur bahasa asing yang sudah diadopsi dan telah disesuaikan dengan bahasa Indonesia, seperti transportasi, edukasi, dan lain-lain. 


\section{Bibliography}

Aditiawarman, Mac. 1994. Bahasa Minangkabau Keturunan Cina di Kota Padang: Satu Kajian Dialek Sosial (Tesis Magister). Bandung: PPs Universitas Padjadjaran. 2004. Preposisi Bahasa Minangkabau. Bandung: Rekayasa Sains.

Aitchison, Jean. 1985. Language Change: Progress or Decay? New York: Univers Books.

Amran, Rusli.1986. Padang Riwayatmu Dulu. Jakarta: Mutiara Sumber Widya.

Appel, René and Pieter Muysken. 1988. Language Contact and Bilingualism. London: Hodder and Stoughton Ltd.

Ayatrohaedi. 1979. Dialektologi: Sebuah Pengantar. Pusat Pembinaan dan Pengembangan Bahasa Departemen Pendidikan dan Kebudayaan.

Bloomfield, Leonard. 1933. Language. London: Campton Printing Ltd.

Chambers, J.K., Peter Trudgill. 1980. Dialectology. Cambridge: Cambridge University Press.

------------. 1990. Dialektologi (diterjemahkan oleh Annuar Aub). Kualalumpur: Dewan Bahasa dan Pustaka Kementerian Pendidikan Malaysia.

Dipodjojo, Asdi S. 1969. Pola Dasar Bahasa Minangkabau. Yogyakarta: FKSS-IKIP.

Downers, William. 1964. Language and Society. Great Britain: The Chaucer Press.

Edwards, John. 1995. Multilingualism. USA: Pinguin Books Ltd.

Finegan, Edward., Niko Besnier. 1989. Language: Its Structure and Use. New York: Harcourt Brace Jovanocich.

Francis, W.M. 1983. Dialectology: An Introduction. London: Longman Inc.
Gumpers, John J. 1971. Language in Social Groups. California: Stanford University Press.

Langecker, Ronald W. 1972. Fundamentals of Linguistic Analysis. New York: Harcourt Jovanovich Inc.

Indah, Atika. 2002. Kinship Terms of Address Use Among Chinese Society in Pondok Padang. Tesis S.1. Padang: Universitas Bung Hatta.

Lim, Sonny. 1988. Baba Malay: The Language of the 'Straits-Born' Chinese. (editor Hein Steinhauer) Papers in Western Austronesian Linguistics No.3,1-61. Pacific Linguistics, A-78. Department of Linguistics Research School of Pasific Studies The Austrlian National University.

Milmory, Lesley. 1987. Observing and Analysing Natural Language. New York: Basil Blackwell Inc.

Moussay, Gérard. 1998. Tata Bahasa Minangkabau. (penerjemah Rahayu S. Hidayat). Jakarta: Kepustakaan Populer Garmedia.

Myers, Carol., Scatton. 1997. Duelling Languages: Gramtical Structure in Codeswitching. Oxford: Clarendon Press.

Suwito. 1983. Pengantar Awal Sosiolinguistik: Teori dan Problema. Salatiga: Henary Offset.

Trudgill, Peter. 1983. On Dialect: Social and Geographical Perspective.Oxford: Basil Blackwell Inc.

Tempo. 2004. Tempo: Etnis Cina di Zaman yang Berubah (edisi khusus 6-22 Agustus 2004).

Vesta, Francis I Di. 1974. Language, Learning, and Cognitive Process. California: Wordsworth Publishing Company Inc. 